\title{
Hazard assessment of glacial lake outburst floods from Kyagar glacier, Karakoram mountains, China
}

\author{
Christoph HAEMMIG, ${ }^{1}$ Matthias HUSS, ${ }^{1,2}$ Hansrudolf KEUSEN, ${ }^{1}$ Josef HESS, ${ }^{3}$ \\ Urs WEGMÜLLER, ${ }^{4}$ Zhigang AO, ${ }^{5}$ Wubuli KULUBAYI ${ }^{6}$ \\ ${ }^{1}$ GEOTEST AG, Zollikofen, Switzerland \\ E-mail: christoph.haemmig@geotest.ch \\ ${ }^{2}$ Department of Geosciences, University of Fribourg, Fribourg, Switzerland \\ ${ }^{3}$ Federal Office for the Environment, Bern, Switzerland \\ ${ }^{4}$ Gamma Remote Sensing AG, Gümligen, Switzerland \\ ${ }^{5}$ Xinjiang Office for Flood Control, Ürümqi, China \\ ${ }^{6}$ Xinjiang Kashgar Hydrographic and Water Resources Survey Bureau, Kashgar, China
}

\begin{abstract}
Kyagar glacier is located in the Chinese Karakoram mountains. The glacier tongue entirely blocks the riverbed in the upper Shaksgam valley and impounds a glacial lake, which was the source of several violent and disastrous glacial lake outburst floods (GLOFs). A GLOF early warning system was implemented between 2011 and 2013. We present an integrative analysis of the hazard potential of Kyagar lake, taking into account the ice flow dynamics of Kyagar glacier as well as the recent surface mass-balance response to climate change. Comparison of two high-resolution digital elevation models (DEMs) for the ice dam shows surface lowering rates of $>5 \mathrm{~m} \mathrm{a}^{-1}$ between 2002 and 2011, leading to a significant reduction in the maximum potential lake volume. However, two DEMs covering the entire glacier for the period 2000-10 indicate mass gains in its central part, and flow speed measurements show an acceleration in this region. This pattern of local ice-thickness changes combined with varying ice flow velocities is typical for surge-type glaciers. The velocity of the glacier surface and of the ice dam between 2011 and 2012 are analyzed at high temporal and spatial resolution, based on feature tracking of synthetic aperture radar (SAR) images.
\end{abstract}

KEYWORDS: glacial lake outburst floods (GLOFs, jökulhlaups), glacier hazards, glacier mass balance, glacier surges, remote sensing

\section{INTRODUCTION}

The disastrous outbursts of glacier-dammed lakes represent a significant hazard in many of the world's mountain ranges (Clague and Mathews, 1973; Ding and Liu, 1992; Richardson and Reynolds, 2000; Björnsson, 2003; Huss and others, 2007a). The sudden drainage of meltwater impounded behind an ice dam, also known as a jökulhlaup, can increase proglacial discharge by more than one order of magnitude over periods of 1 day or less (Liu, 1992; Hewitt and Liu, 2010), and the processes triggering these events are still not fully understood (Sugiyama and others, 2008; Werder and others, 2010). Consequently, predicting the timing of ice-dammed lake outbursts is difficult, and early warning measures are important to reduce the risk to local human settlements. The impact of glacier floods in mountainous regions is known to be particularly pronounced as the proglacial streams often lead into densely populated areas. However, the hazard assessment of glacier lakes at remote and high-elevation sites of the Himalaya, Karakoram and Tien Shan is difficult due to restricted field site accessibility (e.g. Hewitt, 1982).

Yarkant river drains an area of $50248 \mathrm{~km}^{2}$ in the Chinese Karakoram and ranks as number one in terms of flood frequency and damage in Xinjiang. Its glacial outburst floods, with peak discharges of up to $6000 \mathrm{~m}^{3} \mathrm{~s}^{-1}$, originate from a remote ice-dammed glacier lake at $4750 \mathrm{~m}$ a.s.l. in the Shaksgam valley, $\sim 560 \mathrm{~km}$ upstream of the floodplains (Zhang, 1992; Hewitt and Liu, 2010; Fig. 1). The hazardous lake is impounded behind the snout of Kyagar glacier which blocks the riverbed of Shaksgam valley. In the past the lake volume was $\sim 230 \times 10^{6} \mathrm{~m}^{3}$ (Feng, 1991).

The Yarkant river floods may be divided into three types, those produced by (1) meltwater, (2) rainstorm and (3) glacial lake outbursts (Zhang, 1992). Meltwater floods occur in summer, when the ablation is strong due to high temperatures. The peak flow of such a flood is not very large, but its total volume is considerable due to its long duration. Statistics over the last 50 years show that peak flow of meltwater floods at Kaqun hydrographical station exceeded $2000 \mathrm{~m}^{3} \mathrm{~s}^{-1}$ only once (Feng, 1991). In the Yarkant basin, $\sim 50 \%$ of the annual precipitation occurs in June to August (monsoon), coinciding with the ablation period. Thus, a rainstorm flood often concurs with a meltwater flood, thereby amplifying its intensity. Between 1954 and 2007, 13 floods were classified as rainstorm floods; one of these exceeded a peak flow of $2000 \mathrm{~m}^{3} \mathrm{~s}^{-1}$ at Kaqun station (Feng, 1991; Hewitt and Liu, 2010).

In the Tarim basin, most catastrophic floods result from the abrupt drainage of Kyagar lake. Most of these floods occur during late summer to early autumn and often are unexpected. Their peak discharges are generally 2-4.5 times greater than meltwater floods, but the flood volumes are smaller. The volumes of most glacial lake outburst floods (GLOFs) were in the range 40-60 × $10^{6} \mathrm{~m}^{3}$. Between 1954 and 2012, 22 floods were classified as GLOFs (Zhang, 1992; Fig. 2b); two of them exceeded a peak discharge of $6000 \mathrm{~m}^{3} \mathrm{~s}^{-1}$ at Kaqun (Fig. 2a), and five more events are characterized by a peak discharge of $>4000 \mathrm{~m}^{3} \mathrm{~s}^{-1}$, causing 

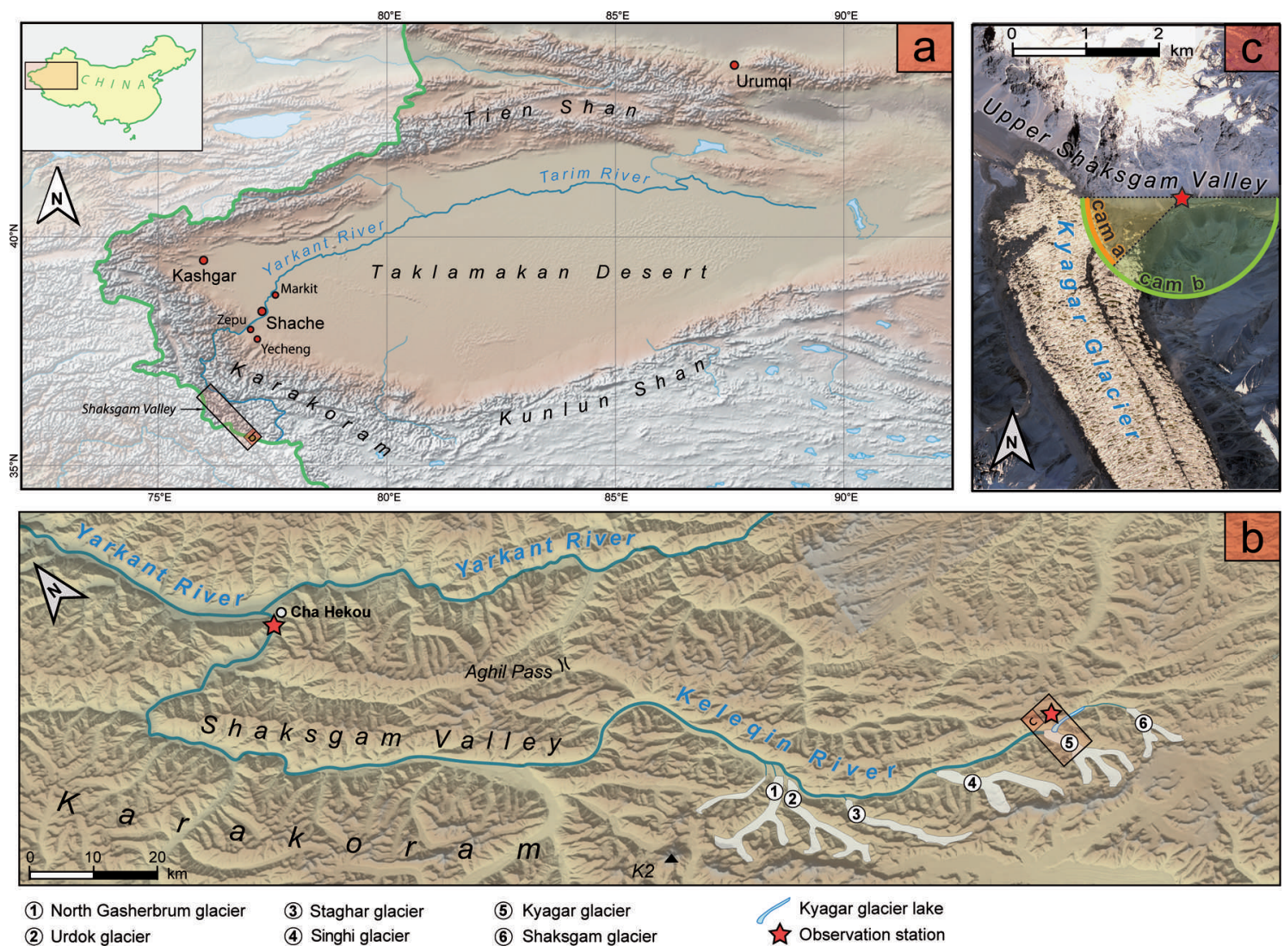

Fig. 1. Situation of (a) Yarkant river in the Tarim basin, (b) Shaksgam valley and (c) Kyagar glacier tongue with the location of the observation station and the indicated camera view directions of the automatic camera.

severe damage in the floodplain of Yarkant river (e.g. Hewitt, 1982). Due to the high peak discharges originating from GLOFs of the ice-dammed lake at Kyagar glacier, Yarkant river exhibits the highest peak flooding in Xinjiang Uyghur Autonomous Region (Feng, 1991). The spontaneous floods pose a threat to more than a million inhabitants on the floodplains of Yarkant river.

In 2009, the floods along Yarkant river became the subject of a Sino-Swiss cooperation project based on a Memorandum of Understanding between the Chinese Ministry of Water Resources and the Swiss Federal Department of the Environment, Transport, Energy and Communications. The project aims to jointly explore ways to improve risk management for coping with the challenges of climate change and to share experiences and know-how between experts in the field. The activities aim at improving the management of GLOFs on Yarkant river and at long-term monitoring of the glaciers causing these floods. The activities are structured into three phases: (1) establishment of an early warning system (EWS) for GLOFs, (2) risk management in the flood areas, and (3) climate change monitoring and analysis.

In this paper, we discuss the behavior of Kyagar glacier and its relation to GLOFs. We explain the concept of a new EWS, combining satellite remote sensing and three automatic terrestrial observation stations, which allows the local authorities to act promptly whenever the ice-dammed
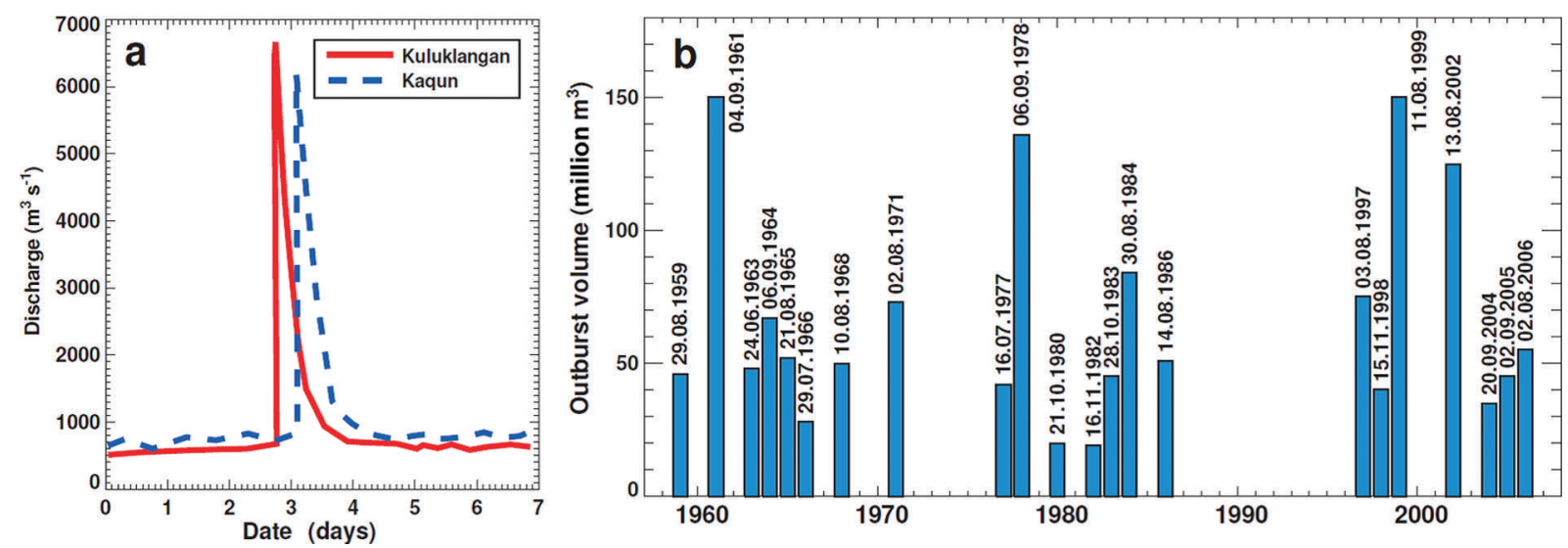

Fig. 2. (a) Observed flood hydrographs of the Kyagar glacier lake outburst of 1961 at two gauging stations at $410 \mathrm{~km}$ (Kuluklangan) and $525 \mathrm{~km}$ (Kaqun) from the lake. (b) Reconstructed glacier flood volumes at Kaqun station since the 1960s with the dates of the floods. Data redrawn after Zhang (1992) and Chen and others (2010). Date format is day.month.year. 

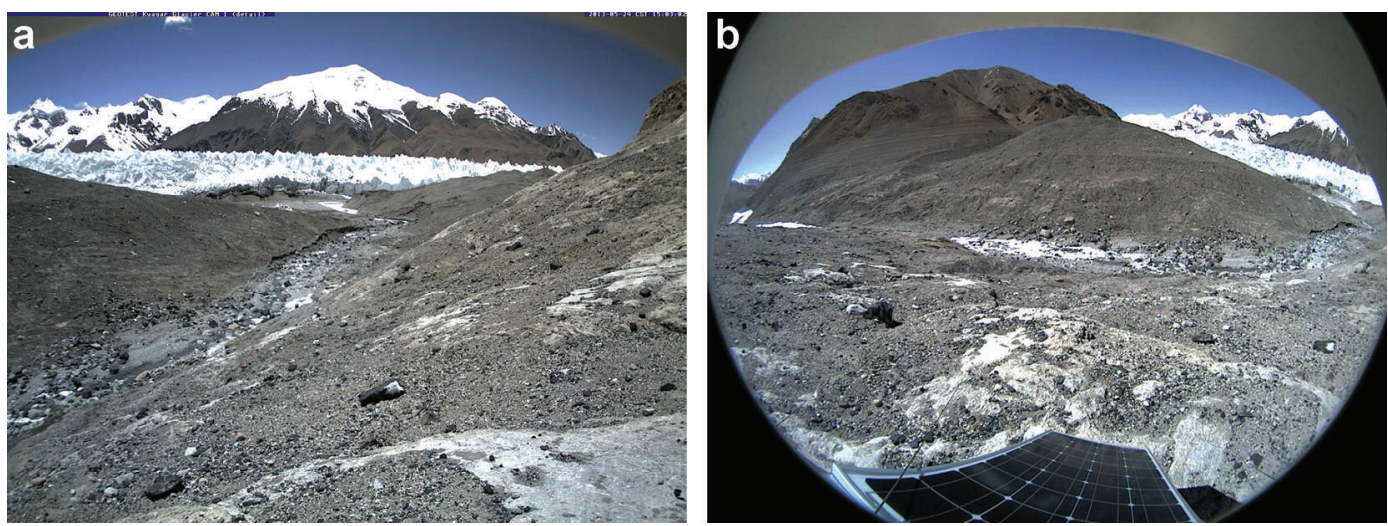

Fig. 3. (a) The empty basin on Kyagar lake, with its ice dam beyond (automatic camera image, 24 May 2013). (b) Empty lake basin with Keleqin river in the valley bottom and Kyagar glacier tongue on the right (automatic camera image, 24 May 2013).

Kyagar lake produces an outburst flood. We also present a joint analysis of a comprehensive set of remote-sensing data from various sources (Heid and Kääb, 2012; Gardelle and others, 2013) that documents the changes in the geometry of Kyagar glacier, as well as variations in its ice flow speed, since 2000. Furthermore, a series of 2 years of synthetic aperture radar (SAR) datasets, acquired at 11 day intervals or multiples thereof, provides an exceptional dataset for analyzing short-term changes in ice flow speed as well as the mass balance of the ice dam as a result of mass gain due to ice flux and mass loss by melt or calving. We draw an integrative picture of recent changes in Kyagar glacier and their connection to the lake formation and drainage, and provide an outlook on the future hazard potential.

\section{STUDY SITE}

Kyagar glacier is a large polythermal valley glacier situated in the Chinese Karakoram mountains in the southwest of Xinjiang Uygur Autonomous Region. The glacier has a total area of $\sim 100 \mathrm{~km}^{2}$ and consists of three separate accumulation basins that join into a $10 \mathrm{~km}$ long and $1.5 \mathrm{~km}$ wide glacier tongue with an average surface slope of $2-3^{\circ}$. The glacier snout is located at $4750 \mathrm{~m}$ a.s.l. The accumulation area of the glacier extends upwards to almost $8000 \mathrm{~m}$ a.s.l. A low annual precipitation of $\sim 200 \mathrm{~mm}$ (Zhang, 1992) causes a high firn line at $\sim 5400 \mathrm{~m}$ a.s.I. In the Shaksgam valley there are a considerable number of surging glaciers (e.g. Copland and others, 2011; Gardelle and others, 2013). For example, a surge of north Gasherbrum glacier $(\sim 50 \mathrm{~km}$ downstream of Kyagar glacier; Fig. 1b) in 2007 was documented in detail by Mayer and others (2011). The glacier terminus advanced by several hundred meters into the Shaksgam valley, nearly blocking the passage of Keleqin river.

The north-flowing Kyagar glacier completely blocks the east-west-oriented upper Shaksgam valley and forms a 50$150 \mathrm{~m}$ high and $1.5 \mathrm{~km}$ wide ice dam (Fig. 1c). The lake impounded behind this ice dam was documented for the first time by Mason (1928) and is known to fill up and drain repeatedly (Zhang, 1992). The hydrological catchment of Kyagar lake has an approximate size of $350 \mathrm{~km}^{2}$ and comprises the source region of Keleqin river, the largest tributary of Yarkant river. Prominent terrestrial marks on the slopes of the Kyagar lake basin indicate ancient shorelines (see Sturm, 1986, for a description of their formation) and, hence, provide evidence for the historical maximum elevation of the lake level, with a lake volume corresponding to $\sim 230 \times 10^{6} \mathrm{~m}^{3}$. Kyagar lake thus used to be one of the largest ice-dammed lakes in the world, with documented regular drainages and down-valley impacts (Hewitt and Liu, 2010). Outburst events of Kyagar lake are most probably characterized by the process of subglacial drainage (see, e.g., Zhang, 1992).

\section{DATA SOURCES}

A Sino-Swiss expedition reached the basin of Kyagar lake in September 2012. An observation station was installed close to the ice dam to take daily photographic images from different viewing angles (Fig. 3) and to record the local meteorological conditions (air temperature, solid and liquid precipitation, humidity, global radiation). In addition, GPS ground control points were acquired, and glaciological observations at the ice dam were carried out. However, because of the remoteness of the study site and the inaccessibility of the glacier surface due to up to $40 \mathrm{~m}$ high ice pinnacles, we base our study mainly on remote-sensing data.

In order to evaluate how the thickness of the ice dam relates to the dynamics of Kyagar glacier and to assess the hazard potential of the impounded lake, we use several sets of remote-sensing data. Using digital elevation models (DEMs) based on satellite imagery, we estimate recent ice thickness changes and quantify variations in glacier surface flow velocity.

To generate an up-to-date reference DEM of the ice dam of Kyagar lake, four scenes of WorldView-2 stereo imagery were acquired on 25 June 2011 for manual photogrammetric stereo-mapping of Kyagar glacier tongue and the lake basin. The DEM has a spatial resolution of $4 \mathrm{~m}$. Another DEM of the same area was established based on two Ikonos $1 \mathrm{~m}$ resolution optical images dating from 20 March and 2 June 2002. The Ikonos 2002 stereo scene was triangulated using the same ground control points as used for the 2011 WorldView-2 stereo imagery. The resulting mapping uncertainty between the 2002 and the 2011 imagery is $\sim \pm 0.5 \mathrm{~m}$ in easting and northing which was confirmed by in situ GPS measurements in the vicinity of the glacier. The elevation difference between the 2002 and the 2011 DEM indicates an uncertainty of $\pm 1 \mathrm{~m}$ over stable terrain. For the glacier, a higher uncertainty of $\sim \pm 2.8 \mathrm{~m}$ due to high surface roughness and water-filled pools is estimated.

Very high-resolution SAR data of the TerraSAR-X satellites were used to identify the hazard potential of Kyagar lake. Based on SAR backscatter, lake surfaces for every image 
Table 1. Satellite data used to identify the GLOF hazard level during 2011 and 2012. All data are from SAR backscatter TerraSAR-X Sensor (except 25 June 2011 from WorldView-2 and 18 June 2011 from COSMO-SkyMed). I = water inflow into the lake basin, $\mathrm{O}=$ water outflow from the lake basin

Date Occurrence of glacier lake Volume of glacier lake Hazard level Water flow into and out of lake basin $\mathrm{m}^{3}$

17 Apr 2011

28 Apr 2011

16 Jun 2011

18 Jun 2011

14 Jul 2011

25 Jul 2011

5 Aug 2011

16 Aug 2011

27 Aug 2011

7 Sep 2011

18 Sep 2011

21 Oct 2011

15 Dec 2011

1 Mar 2012

30 Jun 2012

11 Jul 2012

22 Jul 2012

2 Aug 2012

13 Aug 2012

24 Aug 2012

4 Sep 2012

26 Sep 2012

18 Oct 2012

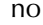

no

no

no

no

yes

yes

yes

yes

yes

yes

no

no

no

no

yes

yes

yes

yes

no

yes

no

no

\begin{tabular}{|c|c|c|}
\hline- & - & I: negligible / O: negligible \\
\hline- & - & I: negligible / O: negligible \\
\hline- & - & $\mathrm{I}$ : minor / O: minor \\
\hline- & - & $\mathrm{I}:$ minor / O: minor \\
\hline- & - & $\mathrm{I}:$ minor / O: minor \\
\hline $\min .45000 ; \max .95000$ & very low & I: large / O: large \\
\hline $\min .45000$; $\max .95000$ & very low & I: large / O: large \\
\hline$\sim 45000$ & very low & I: moderate / O: large \\
\hline $\min .45000 ; \max .95000$ & very low & I: large / O: large \\
\hline $\min .45000$; $\max .95000$ & very low & I: moderate / O: moderate \\
\hline$\sim 50000$ & very low & I: minor / O: moderate \\
\hline- & - & I: negligible / O: minor \\
\hline- & - & I: negligible / O: negligible \\
\hline- & - & I: negligible / O: negligible \\
\hline- & - & I: minor / O: moderate \\
\hline $\min .45000 ; \max .95000$ & very low & I: moderate / O: moderate \\
\hline $\min .45000 ; \max .95000$ & very low & I: moderate / O: moderate \\
\hline $\min .45000 ; \max .95000$ & very low & I: large / O: large \\
\hline$\sim 50000$ & very low & I: moderate / O: moderate \\
\hline- & - & I: moderate / O: moderate \\
\hline $\min .45000 ; \max .95000$ & very low & I: moderate / O: moderate \\
\hline- & - & $\mathrm{I}:$ minor / O: minor \\
\hline- & - & I: negligible / O: minor \\
\hline
\end{tabular}

could be delineated. Lake volumes were calculated using lake shorelines and the detailed reference DEM of the lake basin established in 2011. Hazard levels were estimated as a result of the lake size. Furthermore, the flow regime of Keleqin river (i.e. lake basin water inflow and outflow) was estimated qualitatively using SAR backscatter. The TerraSAR$X$ sensors provide detailed information at $1 \mathrm{~m}$ pixel spacing. These satellite data were continuously analyzed with a repeat-pass period of at least 11 days (Table 1).

In order to analyze the state of Kyagar lake over recent decades, we compiled a total of 65 optical satellite images from various sensors acquired between 1972 and 2011. This imagery allows the calculation of historical glacier lake areas and impounded volumes as well as the visualization of changes in Kyagar glacier. No significant phases of advance and retreat of the glacier terminus are evident, which might explain why Kyagar is not listed as a surge-type glacier by Copland and others (2011). However, because glacier flow at the terminus is perpendicular to a steep rock wall (Fig. 1c), it seems reasonable to expect that glacier changes will be expressed as thickening and thinning rather than advance and retreat.

Information about surface elevation changes for hundreds of glaciers in the Himalaya-Karakoram region is provided by Gardelle and others (2013). For Kyagar glacier, they compared glacier surfaces mapped by the Shuttle Radar Topography Mission (SRTM) in February 2000 with a DEM derived from Satellite Pour l'Observation de la Terre (SPOT) imagery dating from October 2010. The accuracy of retrieved 10 year elevation changes is assumed to be within a few meters, although data quality is slightly inferior in the accumulation area and some mapping errors are evident (Gardelle and others, 2013).
Based on feature-tracking in Landsat imagery, Heid and Kääb (2012) derived longitudinal annual flow speed profiles for several hundred glaciers in different mountain ranges for every year in the period 2000-11, allowing temporal trends in ice flow to be analyzed. Changes in center-line surface ice flow speed in the ablation area of Kyagar glacier are available from an updated dataset (personal communication from T. Heid, 2012). Heid and Kääb (2012) compared annual Landsat images acquired between mid-July and early September and estimated the uncertainty in the flow speed measurements as $\pm 5-6 \mathrm{~m} \mathrm{a}^{-1}$. In order to directly compare displacement rates in individual years with observation period lengths varying between about 300 and 400 days, all flow speeds were normalized to 365 days by assuming constant velocity over the year.

The 21 TerraSAR-X scenes acquired over Kyagar glacier (Table 1) were used for the SAR offset tracking analysis to determine glacier velocities. Their temporal sampling is excellent during the summer and fall periods, when many acquisitions were programmed for monitoring the glacial lake. During winter and spring the intervals are significantly longer. The TerraSAR-X data are at high spatial resolution $(<3 \mathrm{~m})$, enabling high SAR offset tracking accuracies to be achieved.

We estimate distributed ice thickness of Kyagar glacier tongue by inverting assumed ice volume fluxes based on the principles of ice flow mechanics using the approach by Huss and Farinotti (2012). Calculated center-line thicknesses are between $100 \mathrm{~m}$ close to the ice dam, which agrees with the general morphology of the Shaksgam valley, and $\sim 300 \mathrm{~m}$ at $8 \mathrm{~km}$ from the terminus. Uncertainties in inferred thicknesses are considerable, however, as little is known about typical glacier thicknesses in the Karakoram. 


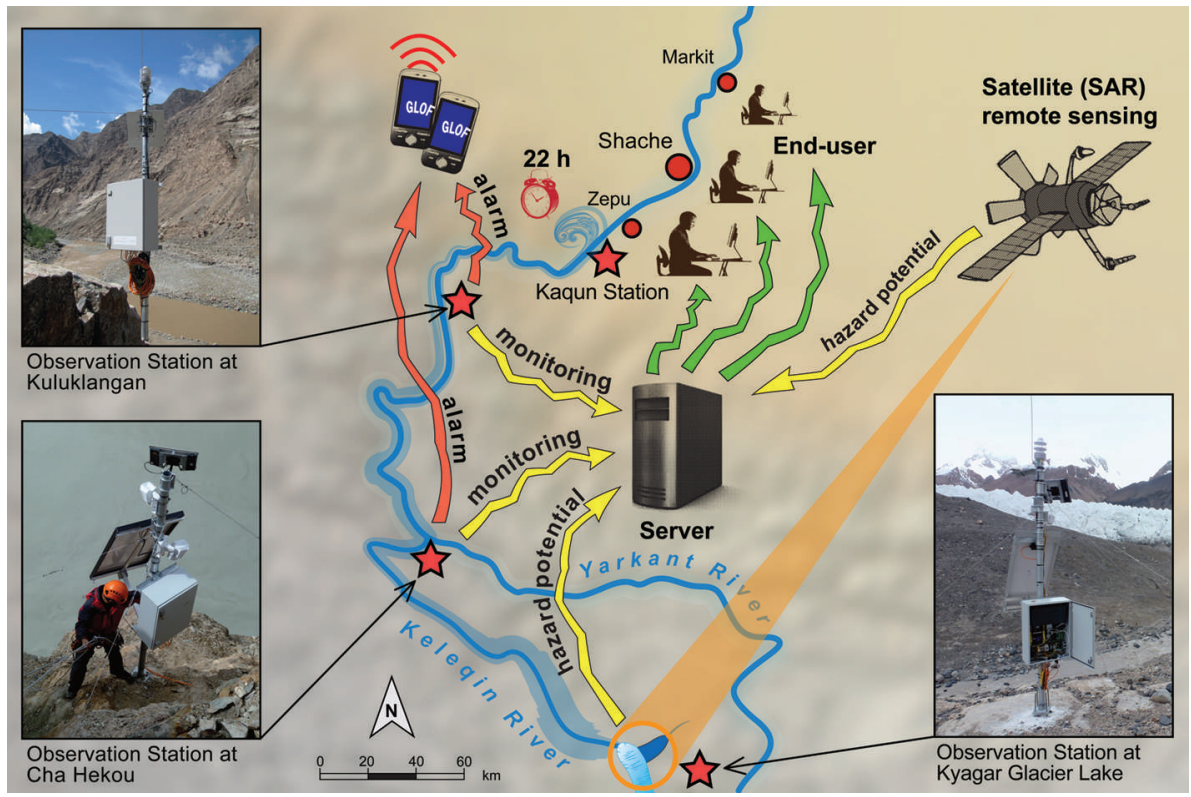

Fig. 4. Concept of the early warning system, combining satellite remote sensing and automatic terrestrial observation stations.

\section{METHODS}

\section{Concept of early warning and monitoring}

Based on the hazard assessment of Kyagar lake and newly gained knowledge about the dynamics of Kyagar glacier, an EWS for GLOFs was implemented. Because the lake is situated in a remote area, our EWS utilized a combination of satellite remote-sensing and automatic terrestrial measurements. Based on the DEM of the empty lake basin from 2011 and periodically acquired SAR images, the evolving morphology of both lake and glacier could be observed within a time interval of 11 days (see Table 1). The current lake volume was then calculated, and the hazard level determined and transmitted to the Chinese decision-makers at the Xinjiang Kashgar Hydrographic and Water Resources Survey Bureau and other authorities (Fig. 4).

In addition to remote-sensing techniques, terrestrial solarpowered observation stations were installed directly at the lake and further downstream along Keleqin and Yarkant rivers at Cha Hekou and Kuluklangan (Fig. 4). Based on camera images acquired by the Kyagar observation station, the lake volume can be estimated using terrestrial markers on the mountain flanks. Hence, it is possible to directly identify the hazard potential on photographs taken by the automatic camera. Another fully automatic observation station is located at Cha Hekou, $\sim 200 \mathrm{~km}$ downstream of Kyagar glacier lake (Figs 1 and 4). There, radar sensors continuously log the water level of Keleqin river, and pictures of its riverbed are taken. Several times a day, all data are automatically transmitted via satellite link to a specific data portal. GLOFs typically show an obvious peak with rapidly rising and declining discharge. If water levels reach a certain threshold, an automatically generated alarm signal is immediately sent to mobile phones of the Chinese authorities. Thus, emergency actions can be initiated. Once the alarm signal is transmitted from the observation station, $\sim 22$ hours remain before the flood reaches the settlement area in the floodplains.

The EWS was completed with a third automatic terrestrial observation station at Kuluklangan (Fig. 4), close to the settlement area. This location covers almost the entire catchment area of Yarkant river and is therefore a suitable place for recording meltwater, rainfall and GLOFs.

\section{SAR offset tracking methodology}

The flow velocity of Kyagar glacier was estimated using SAR offset tracking. This methodology can be used to estimate both the line-of-sight (LOS) displacement and the azimuth displacement between the two acquisition dates (Fatland and Lingle, 2002; Strozzi and others, 2002; Joughin and others, 2004). The displacements were converted from pixel offsets to meters. For the conversion from the LOS and azimuth components to easting and northing it is assumed that the movement is in the horizontal plane. For the flat lower part of the glacier this assumption does not significantly affect the quality of the result, however. In offset tracking, pixel offsets are determined between the two SAR images. These offsets can be determined to a small fraction of a pixel (e.g. 0.05 pixel in ice-free terrain) depending also on factors such as the method or the patch size used, etc. For glacier velocity mapping, the accuracy of the pixel offsets translates to sensitivities in LOS and azimuth direction. In the case of TerraSAR-X, for example, 0.05 pixel (of the original singlelook complex) translates to $\sim 0.1 \mathrm{~m}$ in both azimuth and ground range (assuming horizontal displacement).

Our strategy was to apply the offset tracking for all pairs of close neighbors separated by at most three acquisitions. This ensures that the intervals are generally short and that there is some redundancy in the displacement observations for each interval. The longest intervals are for the wintertime (October to June) when no (or few) scenes were ordered. Including these winter pairs is relevant, however, for obtaining a complete displacement time series. Based on these pairs a time series was then derived using a singular value decomposition method. Some smoothing of the timeseries solution was achieved by introducing constraints on the change in velocity as described by Schmidt and Bürgmann (2003). Apart from the time series, a quality value was determined to quantify how well the derived time series and the individual observations correspond. 


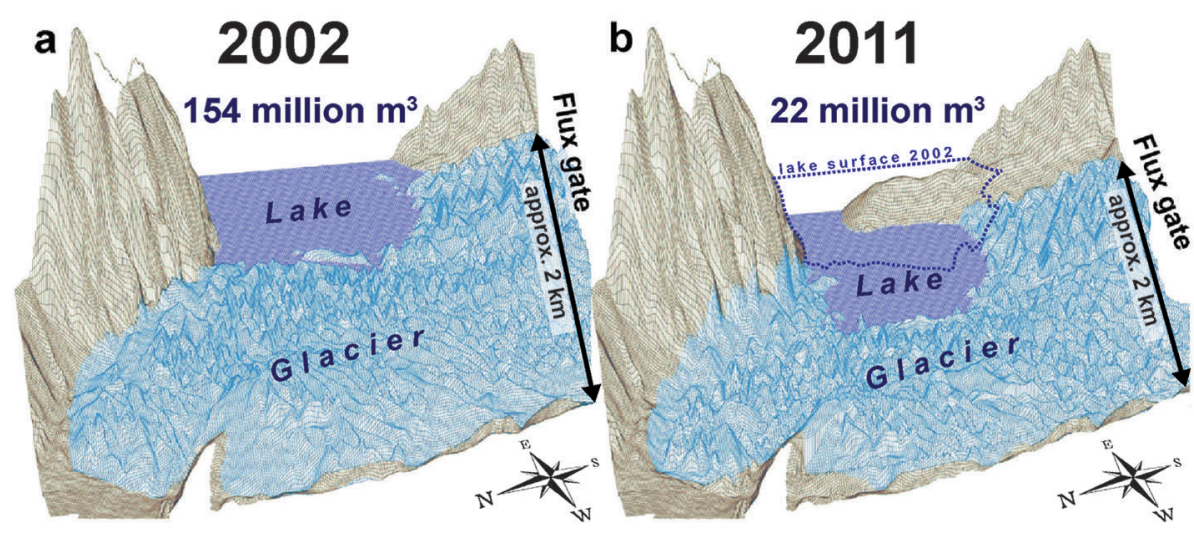

Fig. 5. High-resolution DEMs of the ice dam in 2002 and 2011 and calculated maximum potential lake volume. The block diagrams show only the westernmost section of Kyagar lake.

\section{Calculation of ice volume flux}

Based on the spatially distributed surface flow velocities from SAR offset tracking, we evaluated ice volume fluxes into the region of the ice dam in order to establish a flux budget of the ice dam of Kyagar glacier. We considered a flux gate (Figs 5 and, further below, 7) that represents a glacier cross section perpendicular to flow and is located $\sim 2 \mathrm{~km}$ upstream of the glacier terminus. The cross-sectional distribution of annual surface flow speed $u_{\mathrm{s}}$ was obtained from the total displacement between the first and the last image used for feature-tracking normalized with 365 days.

Vertical flow velocity profiles $u(z)$ across the glacier were calculated using (e.g. Huss and others 2007b)

$$
u(z)=u_{\mathrm{b}}+u_{\mathrm{s}}\left\{1-\left(\frac{h-z}{h}\right)^{n+1}\right\}
$$

where $h$ is the local ice thickness calculated for Kyagar glacier after Huss and Farinotti (2012), $u_{\mathrm{b}}$ is the basal flow speed and $n=3$ is the exponent of Glen's flow law (Glen, 1955). As a first-order approximation, $u_{\mathrm{b}}$ was estimated as $50 \%$ of surface flow. Varying this ratio between $20 \%$ and $80 \%$ had minimal impact $( \pm 10 \%)$ on the calculated volume flux. Applying Eqn (1), the ice volume flux into the ice dam in 2011/12 was able to be calculated, allowing an assessment of the present balance between ablation (melt, calving) and compensation by ice flow.

\section{RESULTS}

\section{Retreat of Kyagar glacier tongue since 2002}

The two high-resolution DEMs covering the glacier terminus showed a considerable mass loss of the ice-dam area $\left(3.5 \mathrm{~km}^{2}\right)$ between 2002 and 2011 (Fig. 5). In total, $18.5 \times 10^{6} \mathrm{~m}^{3} \mathrm{a}^{-1}$ were lost, which corresponds to an average thinning of $48 \mathrm{~m}$ or a thinning rate of $5.3 \mathrm{~m} \mathrm{a}^{-1}$. The height of the ice dam, estimated from the elevation difference between the dam surface and the lake-basin floor, was reduced by more than one-third. No significant changes in glacier area were observed, however, over the last decade. Whereas the down-valley glacier terminus remained almost stable, an enlargement of the lake basin and a recession of the ice dam by $200-420 \mathrm{~m}$ due to calving were evident on the eastern side of the glacier tongue. Despite the major ice surface lowering, the glacier was in contact with the opposite mountain flank, where the ice was protected by a debris layer. The upper Shaksgam valley was thus still completely blocked by Kyagar glacier. The observed thinning of the ice dam had a strong impact on the maximum potential water volume of the glacierdammed lake. Whereas in 2002 a lake volume of $153 \times 10^{6} \mathrm{~m}^{3}$ could potentially have been reached until overtopping of the ice dam, the potential lake volume decreased to only $22 \times 10^{6} \mathrm{~m}^{3}$ in 2011 due to lowering of the glacier tongue (Fig. 5). The relation between ice-dam height and maximum lake volume is thus strongly nonlinear. Flood records indicate a lake outburst volume of roughly $120 \times 10^{6} \mathrm{~m}^{3}$ in 2002 (Fig. 2b). This is also consistent with the lake volume of $95 \times 10^{6} \mathrm{~m}^{3}$ which was calculated using a Landsat image from 9 August 2002 and the DEM of the empty lake basin. No outburst floods were recorded in 2011 and 2012, however, and the fortnightly monitoring of the lake using TerraSAR- $X$ images showed that in these years only a very small lake with a volume of $\sim 0.1 \times 10^{6} \mathrm{~m}^{3}$ existed from July to mid-September (Table 1).

\section{Danger of floods in the past and at present}

Based on historical observations of 22 floods from Kyagar lake since 1960 (Fig. 2; Zhang, 1992; Chen and others, 2010), an empirical relation between lake volume and peak discharge was established. We used the Clague and Mathews (1973) formula

$$
Q=a V^{b}
$$

which calculates peak discharge $Q\left(\mathrm{~m}^{3} \mathrm{~s}^{-1}\right)$ from lake volume $V$ (in $10^{6} \mathrm{~m}^{3}$ ) and where $a$ and $b$ are empirical parameters. We assume $V$ corresponds to the observed flood volume (Fig. 2b). The best fit to the data was found with $a=160$ and $b=2 / 3$. The exponent $b$ was thus consistent with theoretical considerations of outburst events of glacierdammed lakes ( $\mathrm{Ng}$ and Björnsson, 2003), but the parameter a was larger than in other applications of the same empirical formula (e.g. Clague and Matthews, 1973; Huss and others, 2007a), indicating that the floods from Kyagar glacier are more violent. This might be related to the limited width of the ice dam, and the small ice thickness, both of which favor a fast enlargement of drainage channels. Application of the empirical equation to the maximum potential lake volume at present $\left(22 \times 10^{6} \mathrm{~m}^{3}\right)$ indicates that peak discharges of $\sim 1300 \mathrm{~m}^{3} \mathrm{~s}^{-1}$ could be reached. Comparing these values to historical records (Fig. 2) shows that the present hazard potential has decreased considerably over recent years and 


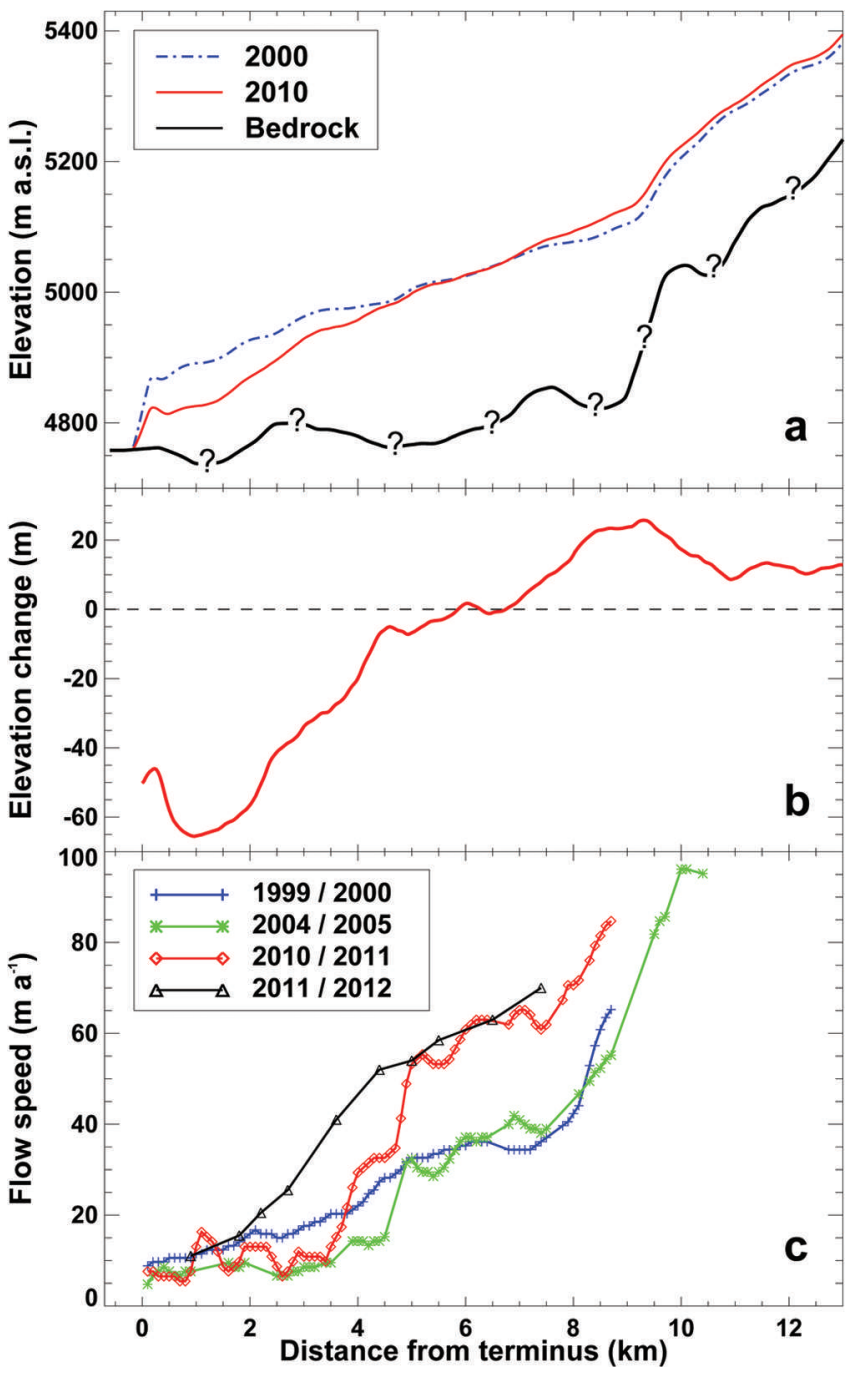

Fig. 6. (a) Glacier surface elevation derived from SRTM and SPOT data on a longitudinal profile of Kyagar glacier according to Gardelle and others (2013). Bedrock elevation is calculated after Huss and Farinotti (2012). (b) Surface elevation change between 2000 and 2010. (c) Observed ice flow speeds for annual periods in 1999/2000, 2004/05 and 2010/11 along the central flowline of Kyagar glacier according to Heid and Kääb (2012), and SAR offsettracking derived flow speeds for 2011/12.

currently is relatively small. However, the possible damage in the Yarkant river floodplain caused by such an event remains uncertain. Further investigations based on fieldverified flood modeling results (i.e. flood hazard indication map) will yield more information about the affected damage potential in the floodplains.

\section{Recent dynamical changes in Kyagar glacier}

Although observations show a substantial decline of the maximum potential lake volume and significant mass loss of the ice dam, projecting the future changes of Kyagar lake requires that the entire glacier system is taken into account. This is especially important as many glaciers in the Karakoram are known to be subject to periodic surges (Hewitt, 2005; Barrand and Murray, 2006; Mayer and others, 2011; Gardelle and others, 2012).

Comparison of the two DEMs from 2000 and 2010 covering the entire glacier surface reveals that Kyagar glacier most likely is a surge-type glacier, as has already been indicated by Gardelle and others (2013). The substantial surface lowering in the terminus region shown by our highresolution DEMs of 2002 and 2011 (Fig. 5) is also captured by the large-scale DEMs provided by Gardelle and others (2013). The two independent datasets agree on the magnitude of the ice loss (Fig. 6a). However, the large-scale DEMs indicate insignificant surface elevation changes on the glacier tongue $5 \mathrm{~km}$ behind Kyagar lake, and even an increase in ice thickness above $5050 \mathrm{~m}$ a.s.l. (Fig. 6a and b). The region with maximum positive elevation changes $(+25 \mathrm{~m}$ in 10 years) is below the equilibrium-line altitude. The surface elevation increase is thus clearly driven by ice flow dynamics and not directly by higher snow accumulation. Elevation changes are also positive for the accumulation area $(\sim+10 \mathrm{~m})$. The observed elevation change pattern (Fig. 6b) is typical for a surge-type glacier in quiescent phase (see Gardelle and others, 2013). The maximum of the surge activity occurred before acquisition of the first DEM, and the ice reservoir is building up.

Changes in ice-flow speed are well suited for recognizing and projecting glacier changes driven by surge activity (e.g. Quincey and others, 2011) although variations in flow can also occur unrelated to glacier surges (e.g. Scherler and Strecker, 2012). Annual surface velocity data along the central flowline of Kyagar glacier by Heid and Kääb (2012) allow an analysis of changes in the dynamics of the glacier tongue over the last decade (Fig. 6c). At $10 \mathrm{~km}$ behind the terminus the ice of Kyagar glacier flows at a velocity of $\sim 100 \mathrm{~m} \mathrm{a}^{-1}$, whereas the glacier is almost stagnant in the region of the ice dam (5-15 $\left.\mathrm{m} \mathrm{a}^{-1}\right)$. Between 1999/2000 and 2004/05, flow speeds declined everywhere along the glacier. Since 2005, however, a significant acceleration has been observed $5-9 \mathrm{~km}$ behind the glacier terminus (Fig. 6c). Surface velocity has almost doubled in a period of a few years in this region, whereas ice flow did not show significant changes at lower elevations. The observed temporal and spatial patterns of ice flow speeds coincide with measured surface elevation changes (Fig. 6): flow speed increases are greatest in regions with a balanced or positive surface elevation change.

The joint analysis of the datasets by Gardelle and others (2013), Heid and Kääb (2012) and our results from SAR offset tracking (2011/12) covering the period 2000-12 indicate that Kyagar glacier currently has a balanced overall mass budget, and that a new surge has been initiated in the upper reaches of the ablation area. If the surge front reached the ice dam, the dam would thicken and, by raising the maximum outburst level of the lake, increase the GLOF hazard potential. Monitoring ice surface velocity and elevation is thus required in order to observe potentially dangerous developments of Kyagar lake.

The evaluation of the TerraSAR-X scenes using SAR offset tracking provided ice surface displacement with great temporal and spatial resolution between early summer 2011 and fall 2012, thus allowing the interpretation of the most recent ice-dynamical changes in Kyagar glacier. The total displacement between the first and last images acquired is shown in Figure 7. Maximum surface velocities correspond to the values of Heid and Kääb (2012), and a downward propagation of the accelerating region between 2011 and 2012 is noted (Fig. 6c). The highest flow speeds were found below the confluence of the two main branches of Kyagar glacier. A clear seasonal variation in ice flow speed, i.e. acceleration in summer and slowdown in winter, is observed (inset of Fig. 7) along the entire ablation area. 


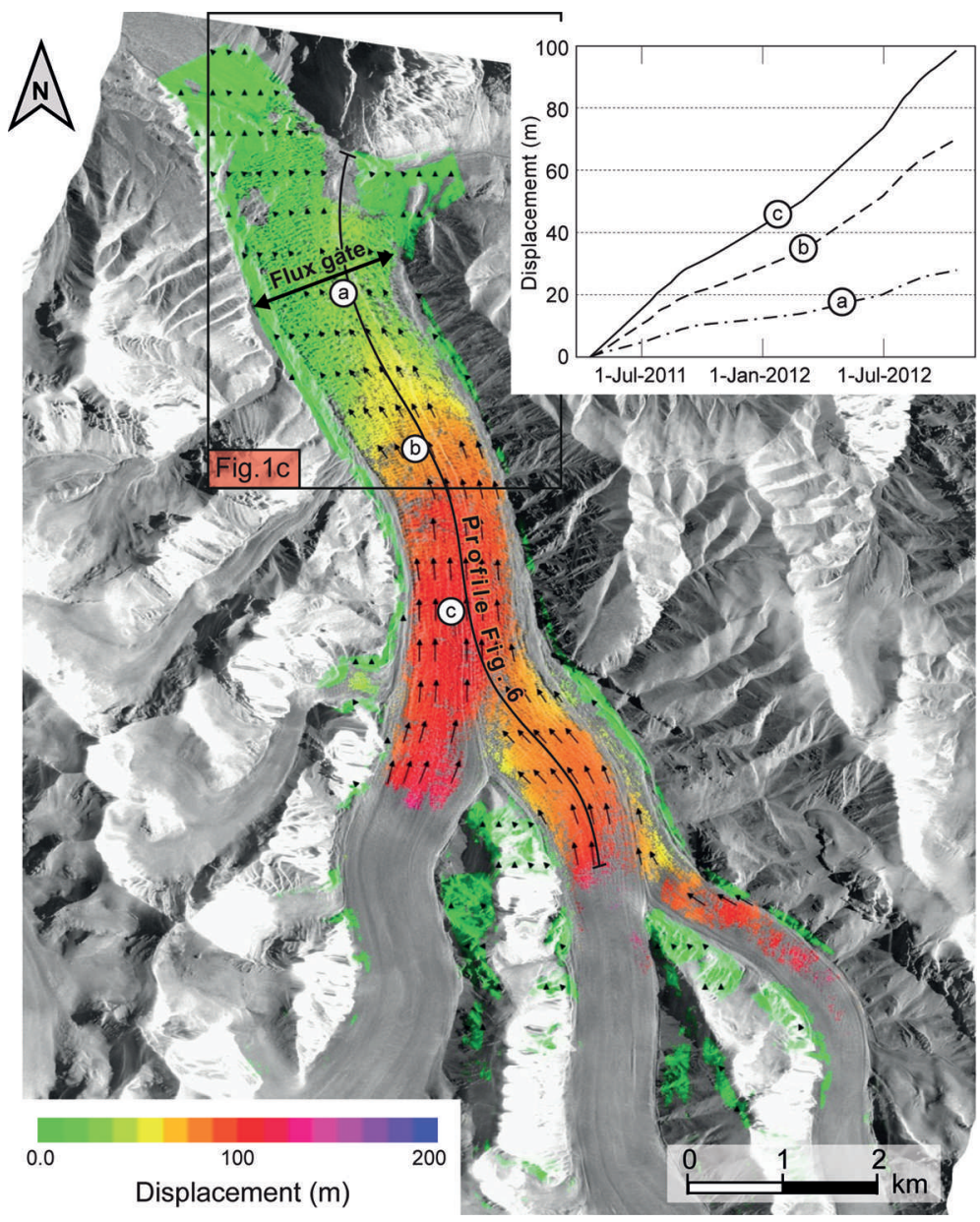

Fig. 7. Total displacement of Kyagar glacier during the 550 days between 17 April 2011 and 18 October 2012. The color indicates displacement, and the small arrows the direction of flow. Time series of cumulative displacement are shown for three selected points $a, b$ and $c$ in the inset.

This indicates that basal sliding is an important component of the flow of Kyagar glacier. The deceleration during the winter is probably related to reduced meltwater input to the glacier bed. The observation that transversal variations in ice flow speed are small (Fig. 7) equally supports the hypothesis that ice deformation is a less important component of flow of Kyagar glacier tongue than basal sliding. By integrating cross-sectional mean annual flow speeds at the flux gate of the ice dam (Fig. 5) and making simple assumptions on basal sliding, we calculated an ice volume flux of $2.5 \pm 1.0 \times$ $10^{6} \mathrm{~m}^{3} \mathrm{a}^{-1}$ entering the terminus region of the glacier using Eqn (1). The confidence interval around this result integrates conservative uncertainty estimates for ice thickness at the flux gate $( \pm 40 \%)$, for SAR-derived annual flow speeds $( \pm 10 \%)$ and for the effect of an unknown percentage of basal sliding on total flux $( \pm 10 \%)$.

Comparison of two image pairs covering an 11 day period around the end of July/beginning of August 2011 and 2012, respectively, revealed a significant acceleration of the glacier between 2011 and 2012 (Fig. 8). Maximum flow speeds increased from $\sim 0.20 \mathrm{~m} \mathrm{~d}^{-1}$ to $0.32 \mathrm{~m} \mathrm{~d}^{-1}$. Moreover, the region with fast glacier flow seemed to be extended in 2012, and center-line flow speeds at the flux gate of the ice dam (Fig. 5) were two to three times higher than in 2011. Although both periods considered had the same length and were in the same season, it is unclear whether flow speed changes can be interpreted as an increase in glacier surge activity. The fast flow in 2012 might be at least partly due to the strongly enhanced snow- and ice-melt water yields observed in Xinjiang during that summer. Continued observations are required to obtain a better understanding of short-term processes affecting the ice flow dynamics of Kyagar glacier tongue.

\section{DISCUSSION}

The combined analysis of different DEMs and datasets on the ice flow speed of Kyagar glacier has shown that the formation of the ice-dammed lake and its floods are probably closely linked to the glacier's surge activity. The substantial reduction of the maximum potential glacier lake volume and the absence of an outburst in 2011 and 2012 are in line with a quiescent phase of the glacier with relatively small ice flow speeds and strong mass losses at the glacier terminus. However, observations indicate the onset of a new glacier surge with a downward propagation of a more active flow regime and an uplift of the glacier surface (Fig. 6). It is yet unclear whether these mass gains in the upper ablation zone can compensate for the strong melt of the ice dam occurring during the last decade.

We are not aware of any documentation of past surges of Kyagar glacier. Previous expeditions to Kyagar lake (Mason, 1928; Zhang, 1992), however, have reported advance phases of the glacier while they were visiting. The clustering of large flood volumes in the late 1990s and early 2000s (Fig. 2b) might indicate that the maximum of the last surge - 

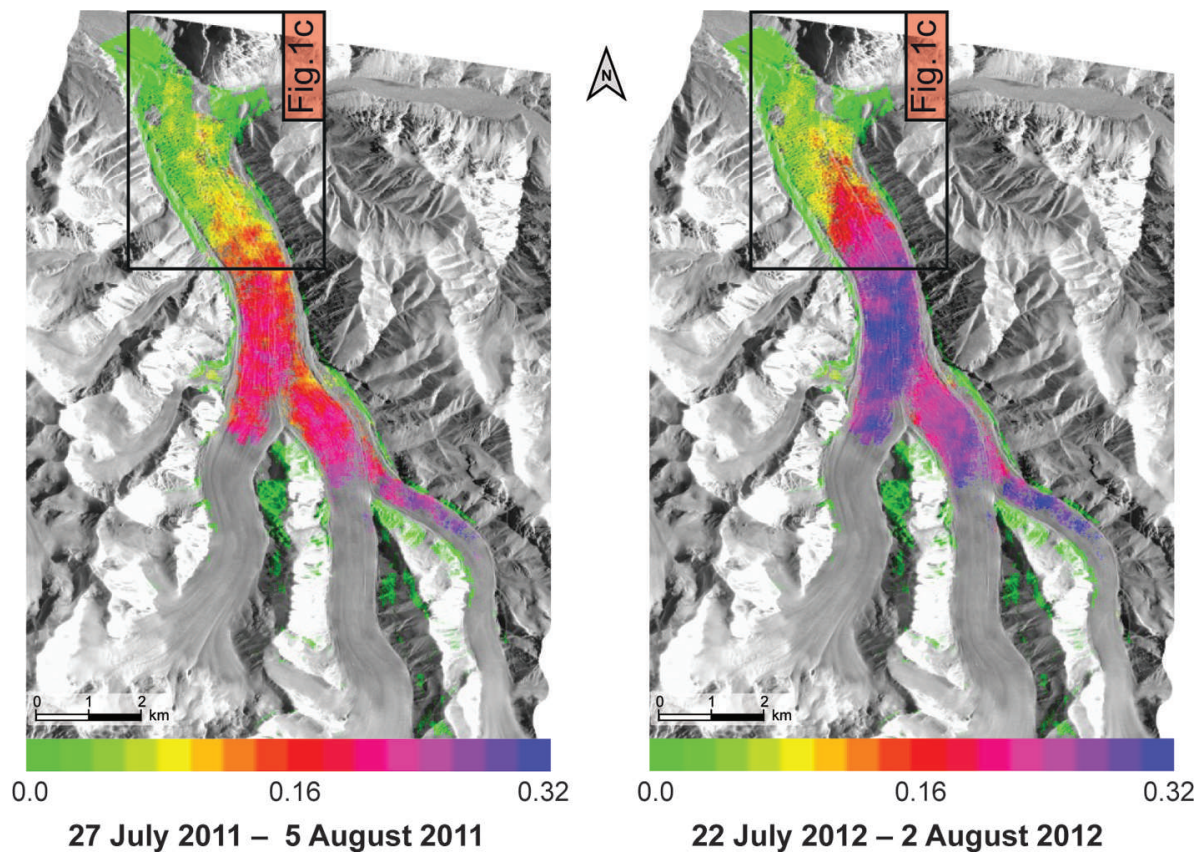

Fig. 8. Glacier surface ice velocity $\left(\mathrm{m} \mathrm{d}^{-1}\right)$ for two 11 day periods in July/August 2011 (left) and 2012 (right).

and thus a thick ice dam in front of Kyagar lake - occurred 10-15 years ago. The records of flood volumes at Kaqun station (Zhang, 1992) are probably not complete and accurate enough to quantitatively interpret the frequency of GLOF occurrence. However, over the last five decades three clusters of large GLOFs have been found: around the 1960s, the 1980s and the 2000s (Fig. 2b). This might lead us to speculate whether there is a relationship between this pattern and the phases of advance and retreat of Kyagar glacier resulting in large lake volumes during glacier advance periods related to surges, and no destructive floods appearing in the records during periods of mass loss of the ice dam.

In order to assess the probability of a future regrowth of the ice dam due to a glacier surge, we evaluated the current balance between melt and ice volume supply by flow into the terminus region of the glacier, which we defined as the glacier ice below the flux gate presently covering an area of $3.5 \mathrm{~km}^{2}$ (Fig. 5). We calculated the annual ice volume lost by ablation by subtracting ice volume flux through the flux gate given by the velocities estimated using SAR offset tracking of 2011/12 from observed mean annual ice volume change in $2002-11$. Currently, only $\sim 12 \%$ of ablation in the terminus region of Kyagar glacier is compensated by ice flow (Fig. 9a), highlighting the strong imbalance of the ice dam at present. Note that (1) ice flux only refers to 2011/12, whereas annual volume change is a mean over the last decade, and (2) a considerable volume of ablation in the terminus region of Kyagar glacier seems to be due to calving of icebergs into the lake. By analyzing changes in the calving front we estimate that $30-50 \%$ of volume loss in 2002-11 can be attributed to this process.
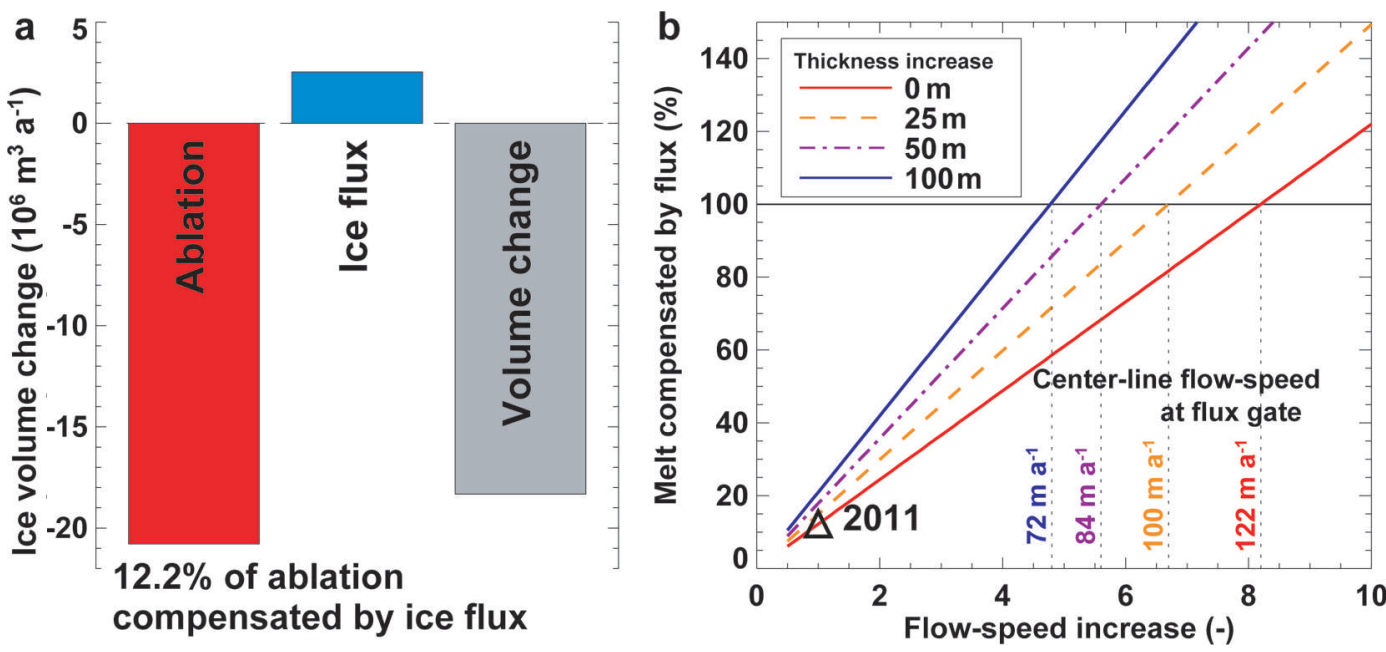

Fig. 9. (a) Present volume balance of the ice dam (see Fig. 5) based on observed volume change 2002-11 and cross-sectional ice flux given by SAR offset tracking (see Fig. 7). The ablation is inferred from volume change and ice flux. (b) Combined scenarios for an increase in ice thickness (relative to 2011) and multiples of surface ice flow speed (relative to 2012; horizontal axis) at the flux gate that are necessary for compensating surface melt in the region of the ice dam (see Fig. 5) by ice flux. 
Assuming the rate of melting and calving (i.e. ablation) on the ice dam of Kyagar glacier remains constant in time, we investigated simple scenarios of changes in ice flux required to yield a balance between ablation and ice supply by ice flow for the ice dam. This was achieved by calculating volume flux with Eqn (1) using changed flow speeds and ice thicknesses at the flux gate. With the same ice thickness at the flux gate as today, an eightfold increase in ice flow speed (i.e. $\sim 120 \mathrm{~m} \mathrm{a}^{-1}$ ) would be required in order to compensate for the volume losses by melting and calving, and to stop the lowering of the ice dam (Fig. 9b). Only an even higher acceleration of the glacier would promote rebuilding of the ice dam, and consequently the possibility of the formation of a new hazardous glacier lake. An increase in flow speed is normally associated with a thickness gain of the glacier (Fig. 6). For this reason, we also performed calculations with uniform thickness increases of between 25 and $100 \mathrm{~m}$ at the flux gate. Even with a thickening of $100 \mathrm{~m}$ which roughly corresponds to the maximum height of the historical lateral moraines, surface flow speed would need to increase by a factor of four to $>60 \mathrm{ma}^{-1}$ at the flux gate in order to compensate for the present ablation in the terminus region (Fig. 9b). These experiments allow a rapid estimation of the probability of a regrowth of the ice dam based on a very few measurements which are easy to achieve using remotesensing techniques. Furthermore, the analysis showed that current ablation rates of the ice dam were sufficiently high that they could be compensated only by a strong acceleration of the glacier, which still lies far beyond the flow speed changes observed over recent years. Only through a substantial thickening of the ablation zone, that might be supported by sustained positive mass balances of Kyagar glacier, does an increase in glacier flow resulting in a considerable readvance of the glacier seem possible.

\section{CONCLUSIONS AND OUTLOOK}

Glacial lakes are linked to complex glaciological processes, are formed in remote mountain areas and are affected by climate change. In addition, the damage potential in the floodplains and the vulnerability of society are constantly growing, as a result of the increasing population density combined with larger economic assets in risk zones. All these aspects need to be considered in cooperation with the decision-makers. The Sino-Swiss project is based on strong collaboration and experience exchange between experts from both countries aimed at implementing practicable, cost-efficient and sustainable measures.

In remote areas where no structural measures (e.g. drainage tunnels) are practicable, the implementation of an automatic EWS based on satellite remote sensing and terrestrial observation stations has proved to be efficient and could significantly reduce damage in the floodplain area. The automatic observation stations are fully operational. Both water level fluctuations and EWS functionality are monitored continuously.

During the last decade, the height of the Kyagar glacier ice dam decreased by more than one-third due to strong melt and reduced ice inflow. Hence, the potential maximal glacial lake volumes declined by $80 \%$ to $\sim 22 \times 10^{6} \mathrm{~m}^{3}$ in 2011. Consequently, the GLOF hazard potential has been significantly reduced. The magnitude and frequency of future GLOFs are directly linked to glacier dynamics, in particular to surge activity. This and previous studies on ice flow velocities and surface elevation changes indicate a surge-type glacier in a currently quiescent phase with a balanced overall mass budget. When a new surge front reaches the glacier tongue this could lead to a thickening of the ice dam and hence an increase in the GLOF hazard potential in the near future. Experiences with the hazard assessment of Kyagar lake show that the remote monitoring of glacier flow characteristics, mass-balance estimations and a solid understanding of the glacier dynamics are necessary elements for implementing an efficient EWS.

\section{ACKNOWLEDGEMENTS}

The project is supported by a cooperation between the Swiss Agency for Development and Cooperation (SDC) and the Federal Office for the Environment (FOEN). On the Chinese side, local authorities, including the Xinjiang Department of Water Resources, the Xinjiang Kashgar Hydrographic and Water Resources Survey Bureau and the Kashgar Management Bureau of Tarim River Basin, support the project. J. Gardelle of LGGE (Laboratoire de Glaciologie et Géophysique de I'Environnement), Grenoble, France, is acknowledged for sharing her elevation change data for Kyagar glacier, and we thank T. Heid of the University of Oslo, Norway, for providing flow speed data since 2000. S. Braun-Clarke proofread the English. Comments by an anonymous reviewer, J. Clague and the scientific editor, F. $\mathrm{Ng}$, were helpful for finalizing the paper.

\section{REFERENCES}

Barrand NE and Murray T (2006) Multivariate controls on the incidence of glacier surging in the Karakoram Himalaya. Arct. Antarct. Alp. Res., 38(4), 489-498 (doi: 10.1657/1523-0430 (2006)38[489:MCOTIO]2.0.CO;2)

Björnsson H (2003) Subglacial lakes and jökulhlaups in Iceland. Global Planet. Change, 35(3-4), 255-271 (doi: 10.1016/S09218181(02)00130-3)

Chen Y, Xu C, Chen Y, Li W and Liu J (2010) Response of glaciallake outburst floods to climate change in the Yarkant River basin on northern slope of Karakoram Mountains, China. Quat. Int., 226(1-2), 75-81 (doi: 10.1016/j.quaint.2010.01.003)

Clague JJ and Mathews WH (1973) The magnitude of jökulhlaups. J. Glaciol., 12(66), 501-504

Copland L and 7 others (2011) Expanded and recently increased glacier surging in the Karakoram. Arct. Antarct. Alp. Res., 43(4), 503-516

Ding Y and Liu J (1992) Glacier lake outburst flood disasters in China. Ann. Glaciol., 16, 180-184

Fatland DR and Lingle CS (2002) InSAR observations of the 1993-95 Bering Glacier (Alaska, U.S.A.) surge and a surge hypothesis. J. Glaciol., 48(162), 439-451 (doi: 10.3189/ 172756502781831296)

Feng Q (1991) Characteristics of glacier outburst flood in the Yarkant river, Karakorum mountains. GeoJournal, 25(2-3), 255-263 (doi: 10.1007/BF02682195)

Gardelle J, Berthier E and Arnaud Y (2012) Slight mass gain of Karakoram glaciers in the early 21st century. Nature Geosci., 5(5), 322-325 (doi: 10.1038/ngeo1450)

Gardelle J, Berthier E, Arnaud Y and Kääb A (2013) Region-wide glacier mass balances over the Pamir-Karakoram-Himalaya during 1999-2011. Cryosphere, 7(4), 1263-1286 (doi: 10.5194/ tc-7-1263-2013)

Glen JW (1955) The creep of polycrystalline ice. Proc. R. Soc. London, Ser. A, 228(1175), 519-538 (doi: 10.1098/rspa. 1955.0066) 
Heid T and Kääb A (2012) Repeat optical satellite images reveal widespread and long term decrease in land-terminating glacier speeds. Cryosphere, 6(2), 467-478 (doi: 10.5194/tc-6467-2012)

Hewitt K (1982) Natural dams and outburst floods of the Karakorum Himalaya. IAHS Publ. 138 (Symposium at Exeter 1982 Hydrological Aspects of Alpine and High Mountain Areas), 259-269

Hewitt K (2005) The Karakoram anomaly? Glacier expansion and the 'elevation effect', Karakoram Himalaya. Mt. Res. Dev., 25(4), 332-340 (doi: 10.1659/0276-4741(2005)025[0332: TKAGEA]2.0.CO;2)

Hewitt K and Liu J (2010) Ice-dammed lakes and outburst floods, Karakoram Himalaya: historical perspectives on emerging threats. Phys. Geogr., 31(6), 528-551 (doi: 10.2747/0272-3646. 31.6.528)

Huss M and Farinotti D (2012) Distributed ice thickness and volume of all glaciers around the globe. J. Geophys. Res., 117(F4), F04010 (doi: 10.1029/2012JF002523)

Huss M, Bauder A, Werder M, Funk M and Hock R (2007a) Glacier-dammed lake outburst events of Gornersee, Switzerland. J. Glaciol., 53(181), 189-200 (doi: 10.3189/ 172756507782202784)

Huss M, Sugiyama S, Bauder A and Funk M (2007b) Retreat scenarios of Unteraargletscher, Switzerland, using a combined ice-flow mass-balance model. Arct. Antarct. Alp. Res., 39(3), 422-431

Joughin I, Abdalati W and Fahnestock MA (2004) Large fluctuations in speed on Greenland's Jakobshavn Isbræ glacier. Nature, 432(7017), 608-610 (doi: 10.1038/ nature03130)

Liu J (1992) Jökulhlaups in the Kunmalike River, southern Tien Shan Mountains, China. Ann. Glaciol., 16, 85-88

Mason K (1928) The exploration of Shaksgam Valley and Aghil Ranges, 1926. (Records of the Survey of India, Vol. 22) Survey of India, Dehra Dun

Mayer C, Fowler AC, Lambrecht A and Scharrer K (2011) A surge of North Gasherbrum Glacier, Karakoram, China. J. Glaciol., 57(205), 904-916 (doi: 10.3189/002214311798043834)
$\mathrm{Ng} F$ and Björnsson $\mathrm{H}$ (2003) On the Clague-Mathews relation for jökulhlaups. J. Glaciol., 49(165), 161-172 (doi: 10.3189/ 172756503781830836)

Nye JF (1976) Water flow in glaciers: jökulhlaups, tunnels and veins. J. Glaciol., 17(76), 181-207

Quincey DJ, Braun M, Glasser NF, Bishop MP, Hewitt K and Luckman A (2011) Karakoram glacier surge dynamics. Geophys. Res. Lett., 38(18), L18504 (doi: 10.1029/2011GL049004)

Richardson SD and Reynolds JM (2000) An overview of glacial hazards in the Himalayas. Quat. Int., 65-66(1), 31-47 (doi: 10.1016/S1040-6182(99)00035-X)

Scherler D and Strecker MR (2012) Large surface velocity fluctuations of Biafo Glacier, central Karakoram, at high spatial and temporal resolution from optical satellite images. J. Glaciol., 58(209), 569-580 (doi: 10.3189/2012JoG11J096)

Schmidt DA and Bürgmann R (2003) Time-dependent land uplift and subsidence in the Santa Clara valley, California, from a large interferometric synthetic aperture radar data set. J. Geophys. Res., 108(B9), 2416 (doi: 10.1029/2002JB002267)

Shi $Y$ and 6 others (2007) Recent and future climate change in northwest China. Climatic Change, 80(3-4), 379-393 (doi: 10.1007/s10584-006-9121-7)

Strozzi T, Luckman A, Murray T, Wegmüller $U$ and Werner $\mathrm{CL}$ (2002) Glacier motion estimation using satellite-radar offsettracking procedures. IEEE Trans. Geosci. Remote Sens., 40(11), 2834-2391 (doi: 10.1109/TGRS.2002.805079)

Sturm M (1986) Formation of a strandline during the 1984 jökulhlaup of Strandline Lake. Arctic, 39(3), 267-269

Sugiyama S, Bauder A, Huss M, Riesen P and Funk M (2008) Triggering and drainage mechanisms of the 2004 glacierdammed lake outburst in Gornergletscher, Switzerland. J. Geophys. Res., 113(F4), F04019 (doi: 10.1029/2007JF000920)

Werder MA, Bauder A, Funk M and Keusen H-R (2010) Hazard assessment investigations in connection with the formation of a lake on the tongue of Unterer Grindelwaldgletscher, Bernese Alps, Switzerland. Natur. Hazards Earth Syst. Sci. (NHESS), 10(2), 227-237 (doi: 10.5194/nhess-10-227-2010)

Zhang X (1992) Investigation of glacier bursts of the Yarkant River in Xinjiang, China. Ann. Glaciol., 16, 135-139 